\title{
ARTICLE
}

\section{Compounds isolated from Salinispora arenicola of the Gulf of California, México}

\author{
Compuestos aislados de Salinispora arenicola \\ del Golfo de California, México \\ Ana M. Íñiguez-Martínez ${ }^{1,2}$, Faviola Cardoso-Martínez ${ }^{1,3}$, José de la Rosa ${ }^{3}$, \\ Mercedes Cueto ${ }^{3}$, Ana Díaz-Marrero ${ }^{3,4}$, José Darias ${ }^{3}$, Amayaly \\ Becerril-Espinosa ${ }^{1}$, Luis J. Plata-Rosas ${ }^{2}$ \\ and Irma E. Soria-Mercado ${ }^{1}$
}

\begin{abstract}
${ }^{1}$ Facultad de Ciencias Marinas, Universidad Autónoma de Baja California, km 103 Carretera Tijuana-Ensenada, Baja California, México. iesoria@uabc.edu.mx

${ }^{2}$ Centro Universitario de la Costa, Universidad de Guadalajara, Av. Universidad de Guadalajara No. 203, Puerto Vallarta, Jalisco, México ${ }^{3}$ Instituto de Productos Naturales y Agrobiología, C.S.I.C., Av. Astrofísico F. Sánchez, 3. La Laguna, 38206, Tenerife, España ${ }^{4}$ Instituto Universitario de Bioorgánica AG, Centro de Investigaciones Biomédicas de Canarias (CIBICAN), Universidad de La Laguna, Av. Astrofísico F. Sánchez, 2, 38206. La Laguna, Tenerife, España
\end{abstract}

Resumen.- La actinobacteria marina AMS370, identificada mediante comparación de las secuencias del gen 16S del ARNr como Salinispora arenicola, fue aislada a partir de sedimento del Golfo de California, México. De su extracto semi-polar, se aislaron 8 compuestos conocidos: ácido-4-Hidroxi-fenil acético (1), 5-Metil-2-metilen-2,3-dihidro-1H-pirimidin-4-ona (2), 1H-Pirimidin2,4-diona (3), ácido-3-amino-5-hidroxi-benzoico (4), 2-(4-Amino-imidazol-[4,5-d]piridazin-1-il)-5-hidroximetil-4-metil-tetrahidrofuran-3-ol (5), Acrilato de 3-(4-Hidroxi-genil)-metilo (6), 3-Bencil-6-isobutil-piperazin-2,5-diona (7) y 5,8-epidioxi-(22E,24R)ergosta-6,22-dien-3-ol (Peróxido de Ergosterol) (8). La identificación química fue realizada mediante comparación de sus espectros de RMN con los espectros de los compuestos originales. Ésta sería la primera ocasión que el compuesto 4 se reporta como un producto natural a partir del género Salinispora. El extracto crudo y todas sus fracciones fueron ensayadas contra Bacillus cereus, Escherichia coli, Enterococcus faecalis, Klebsiella pneumoniae, Proteus mirabilis, Staphylococcus aureus, Salmonella sp. y Candida albicans para probar su actividad antibiótica y antifúngica en el caso de la última especie. Asimismo se evaluó su actividad citotóxica frente a las líneas celulares de cáncer de mama (MCF-7), cervicouterino (HeLa) y colorectal (HCT-116). Solamente el extracto crudo semipolar y las fracciones 5.1 y 5.2 resultaron activas contra Klebsiella pneumoniae y Staphylococcus aureus.

Palabras clave: Actinobacteria marina, actividad antibiótica, actividad citotóxica, Golfo de California

\begin{abstract}
The marine actinobacterium AMS370, identified as Salinispora arenicola by 165 rRNA amplified gene comparison, was isolated from sediments of the Gulf of California, Mexico. From its semi-polar extract, 8 known compounds were isolated: 4Hydroxy-phenyl acetic acid (1), 5-Methyl-2-methylene-2,3-dihydro-1H-pyrimidin-4-one (2), 1H-Pyrimidine-2,4-dione (3), 3-amino5-hydroxy-benzoic acid (4), 2-(4-Amino-imidazol-[4,5-d]pyridazin-1-yl)-5-hydroxymethyl-4-methyl-tetrahydro-furan-3-ol (5), 3(4-Hydroxy-phenyl)-acrylic acid methyl ester (6), 3-Benzyl-6-isobutyl-piperazine-2,5-dione (7) and 5,8-epidioxy-(22E,24R)-ergosta6,22-dien-3-ol (Ergosterol peroxide) (8). The chemical identification was performed by comparison of their NMR spectra against the NMR spectra of the original compounds. This is the first time that compound 4 is reported as a natural product obtained from the Salinispora genus. The crude extract and all the fractions obtained were tested for antibiotic activity against Bacillus cereus, Escherichia coli, Enterococcus faecalis, Klebsiella pneumoniae, Proteus mirabilis, Staphylococcus aureus, Salmonella sp. and antifungic activity against Candida albicans. Also, breast cancer (MCF-7), cervical cancer (HeLa) and colorectal cancer cell lines (HCT-116) were tested to determine their cytotoxic activity. Only the semi-polar crude extract and its fractions 5.1 and 5.2 were active against Klebsiella pneumoniae and Staphylococcus aureus.
\end{abstract}

Key words: Marine actinobateria, antibacterial activity, cytotoxic activity, Gulf of California

\section{INTRODUCTION}

The order Actinomycetales harbor Gram positive bacteria that belong to the Actinobacteria phylum. This order represents the most important prokaryote organisms known due to the great diversity of bioactive compounds produced, among which we 
can find antibiotics, antitumor and immunosuppressive agents. Their DNA base composition is characterized by a high percentage of guanine + cytosine $(\mathrm{G}+\mathrm{C})$ (Fenical \& Jensen 2006, Bull \& Stach 2007, Olano et al. 2009), higher than any other bacteria. Members of this class are known as actinomycetes or actinobacteria (Jensen \& Lauro 2008) and include the Streptomyces genus, which is the main source of antibiotics discovered to date (Bérdy 2005). Currently, a large number of institutions around the world have developed research programs with the sole purpose of discovering new metabolites with pharmaceutical applications (Ellaiah et al. 2004) for its use in the treatment of human illnesses, as well as those with biotechnological applications (Jemimah et al. 2011). These studies have provided new knowledge of their taxonomy and description of new taxa, some of them without terrestrial counterparts (Olano et al. 2009) and many with salt requirements such as Salinispora (Feling et al. 2003, Maldonado et al. 2005, Becerril-Espinosa et al. 2013, Ng et al. 2014), Serinicoccus (Yi et al. 2004), Salinibacterium (Han et al. 2005) and Sciscionella (Tian et al. 2009).

The Salinispora genus is one of the most prolific and widely distributed in tropical and subtropical marine sediments both in the Pacific and the Atlantic Ocean (Mincer et al. 2002, Maldonado et al. 2005, Mincer et al. 2005, Jensen \& Mafnas 2006). There are 3 species formally described, S. arenicola, S. tropica (Maldonado et al. 2005) and S. pacifica (Ahmed et al. 2013) from which a large number of compounds with cytotoxic activity against colorectal carcinoma cells (HCT-116) have been isolated, including arenicolide, salinisporamide A, staurosporine and arenimycin (Feling et al. 2003, Gerner \& Meyskens 2004, Williams et al. 2007a, b; Fenical et al. 2009, Asolkar et al. 2010).

Salinisporamide A, is currently in clinical trials as one of the most potent anticancer agent isolated until today (Fenical et al. 2009). Metabolomics approach has been used to characterize the variation in secondary metabolites production when the cultures are subjected to different conditions. In the obligate marine Salinispora genus from The Great Barrier Reef (GBR) sponges were monitored by LC-MS analysis (Bose et al. 2014, 2015). Although marine Actinobacteria have been recognized as a major source of drugs, little is known about their diversity and ecological distribution in the Mexican territory, which has a coastal and ocean area comprising about 1,378,620 $\mathrm{km}^{2}$ representing more than $50 \%$ of the land territory (De la Lanza 2004). This provides a great opportunity to learn more about its microbial diversity and potential applications in human disease treatments. Here, we carried out the isolation, purification and structural elucidation of the compounds found in the AMS370 strain obtained from sediments of the Gulf of
California, as well as the molecular identification of the Salinispora arenicola strain.

\section{Materials AND METHODS}

\section{SAMPle COLlection}

An extensive sampling along the Gulf of California was made in November 2007 and April 2008. 126 samples of sediment were collected at depths between 0 and $300 \mathrm{~m}$, in 7 different areas located in the western part of the Gulf of California, from which, 1497 strains with actinomycete morphology were isolated (Becerril-Espinosa et al. 2013). The maximum strain recovery was achieved near Danzante Island and in the central part of the Gulf, specifically in Los Angeles Bay and Concepcion Bay. From all the obtained strains, AMS370 isolated from Los Angeles Bay, showed strictly marine characteristics, that is, it required salt to grow. Torres-Beltrán et al. (2012) concluded this after growing the bacteria in a culture medium containing deionized water and no growth was observed over a period of time. It also showed antibiotic activity (Torres-Beltrán et al. 2012) for which it was selected for this study.

\section{ACtinomycete isolation}

The strain, cryopreserved in $30 \%$ glycerol at $-70^{\circ} \mathrm{C}$, was activated in Petri dishes in $\mathrm{A} 1$ medium (1.8\% agar, $0.1 \%$ starch, $0.02 \%$ bactopeptone, and yeast extract $0.04 \%$ in sea water) supplemented with $10 \mathrm{mg} \mathrm{l}^{-1}$ of cycloheximide as an antifungal agent, and rifampicin $\left(0.5 \mathrm{mg} \mathrm{l}^{-1}\right)$ as an antibiotic and incubated at $28^{\circ} \mathrm{C}$ under aerobic conditions for 3-4 weeks (Torres-Beltrán et al. 2012, Becerril-Espinosa et al. 2013).

The spores were inoculated into $10 \mathrm{ml}$ of liquid A1 medium for 7 days with continuous shaking at $215 \mathrm{rpm}$ and $28^{\circ} \mathrm{C}$. After the incubation period, the culture was transferred to $100 \mathrm{ml} \mathrm{A} 1$ liquid medium, and allowed time for optimal growth. Subsequently this volume was transferred to 11 of the same medium for a week to achieve maximum optical density.

\section{Molecular IDENTIFICATION}

Pure bacterial strains were cultured in $25 \mathrm{ml}$ of medium A 1 and shaken at $215 \mathrm{rpm}$ and $28^{\circ} \mathrm{C}$ for 7 days. Genomic DNA was extracted using Gontang et al. (2007) method. 16rRNA genes were PCR amplified using the primers FC27 (5030AGAGTTTGATCCTGGCTCAG) and RC1492 (50-30TA CGGCTACCTTGTTACGACTT) and initial naturalization at $95^{\circ} \mathrm{C}$ for $15 \mathrm{~min}$ followed by $72^{\circ} \mathrm{C}$ for $7 \mathrm{~min}$. PCR products were purified with a Qiagen QIAquik PCR cleanup kit using protocols by the manufacturer (Qiagen Inc. Chatsworth, CA.). Sequence was obtained using the primers listed above at 
SeqXcel, Inc. (http://www.seq_xcel.com/) using the BigDye terminator Cycle Sequencing Chemistry 3.1 technique and a Genetic Analyzer ABI Prism 3100 (Applied Biosystem). The forward and reverse 16SrRNA sequence obtained from this strain was assembled and analyzed using BLAST (Basic Local Alignment Search Tool) (Altschul et al. 1990) available on the NCBI website (http://www.ncbi.nlm.nih.gov/). Sequences were aligned using CrustalX and imported into the Bioedit program (Hall \& Brown 2001). The NCBI and GenBank database search using BLAST algorithm for highly similar sequences showed a $100 \%$ sequence identity to Salinispora arenicola 'A' [strain AMS300, Accession number (gb/HQ873946)].

\section{Preparation of extracts}

Crude extracts were obtained after the fermentation period ended; the broth was separated from the cell mass by filtration in order to process both samples separately. Broth was extracted with ethyl acetate (EtOAc) and concentrated by reduced pressure distillation (semi-polar extract). Amberlite XAD7HP $\left(20 \mathrm{~g} \mathrm{l}^{-1}\right)$ was added to the cell mass and stirred for $3 \mathrm{~h}$, then the resin was extracted with methanol $(\mathrm{MeOH})(40 \mathrm{~g}$ $\mathrm{l}^{-1}$ ) and stirred for $2 \mathrm{~h}$, then filtered and concentrated (polar extract). Both extracts were subjected to analysis of cytotoxic, antibiotic and antifungal activity.

\section{SeParation of the SEmi-polar fraction (EtOAC)}

The crude extract of the semi-polar fraction $(783.3 \mathrm{mg}$ ) was fractionated by reverse phase chromatography using a $2.5 \mathrm{~cm}$ inner diameter column with silica gel 100C-18 (Fluka, 60758) to a height of $10.0 \mathrm{~cm}$ (Blunt et al. 1987) and $\mathrm{H}_{2} \mathrm{O} 100 \%$, mixtures of $\mathrm{H}_{2} \mathrm{O}-\mathrm{MeOH}(3: 1,3: 2,2: 3$ and $1: 4)$, $\mathrm{MeOH}$ (Anhydrous, Sigma-Aldrich) followed by EtOAc (Anhydrous, Sigma-Aldrich) and $\mathrm{CH}_{2} \mathrm{Cl}_{2}$ (Anhydrous, Sigma-Aldrich) to $100 \%$ each were used as mobile phase, giving a total of 8 fractions. The course of the chromatography was monitored by thin layer chromatography analysis (TLC) and protonic nuclear magnetic resonance ( $\left.{ }^{1} \mathrm{HNMR}\right)$ as well as by antibiotic activity assays.

TLC were performed over silica gel $60 \mathrm{~F}_{254}$ aluminum base preparative plates $(20 \times 20 \mathrm{~cm})$ (Merck, 105554), and developed with fluorescence detection in an Ultra Violet (UV) lamp LourmatVilberta at a wavelength of $254 \mathrm{~nm}$, oleum $\left[\mathrm{H}_{2} \mathrm{SO}_{4}: \mathrm{H}_{2} \mathrm{O}: \mathrm{AcOH}(1: 4: 20)\right]$ and phosphomolybdic acid reagent $\left[10 \mathrm{~g}\right.$ of $\mathrm{H}_{3}\left[\mathrm{P}\left(\mathrm{Mo}_{3} \mathrm{O}_{10}\right)_{4}\right], 4 \mathrm{~g}$ of $\mathrm{Ce}\left(\mathrm{SO}_{4}\right)_{2} \cdot 4 \mathrm{H}_{2} \mathrm{O}, 2$ $\mathrm{ml}$ of $\mathrm{H}_{2} \mathrm{SO}_{4}$ and $470 \mathrm{ml} \mathrm{H}_{2} \mathrm{O}$ ] spray solution followed by heating.

According to the ${ }^{1} \mathrm{HNMR}$ spectra and/or bioactivity, the selected fractions to undergo further analysis were fractions 2 , 4,5 , and 6 . These fractions were processed as follows:

\section{Fraction $2\left(\mathrm{H}_{2} \mathrm{O}-\mathrm{MeOH} 3: 1\right)$}

This fraction $(119.5 \mathrm{mg}$ ) was purified by gel filtration chromatography on Sephadex LH-20 (int $\phi=3.5 \mathrm{~cm}$; HGEL= $22.0 \mathrm{~cm}$ ) eluted with $100 \% \mathrm{MeOH}$ and yielded 60 subfractions.

\section{Fraction $4\left(\mathrm{H}_{2} \mathrm{O}-\mathrm{MeOH} 2: 3\right)$}

Sephadex LH-20 (int $\phi=3.5 \mathrm{~cm} ; \mathrm{HGEL}=22.0 \mathrm{~cm})$ was used to purify fraction $4(71.6 \mathrm{mg})$. This chromatography was eluted with a mixture of $\mathrm{CH}_{2} \mathrm{Cl}_{2}-\mathrm{Hex}-\mathrm{MeOH}$ (3:1:1) to yield 2 subfractions [4.1 (14 mg) and 4.2 (13.1 mg)].

Subfraction 4.1 was re-chromatographed using identical conditions that in the previous step eluting with $100 \%$ methanol.

Subfraction 4.2 was purified by HPLC [Supelco Analytical If Ascentis (25 cm x $10 \mathrm{~mm}$ )], gradient Hex-EtOAc 10:90 to

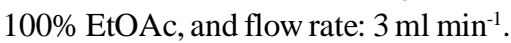

\section{Fraction $5\left(\mathrm{H}_{2} \mathrm{O}-\mathrm{MeOH}\right.$ 1:4)}

For fraction $5(46.5 \mathrm{mg})$, biological activity guided the purification process. The sample was chromatographed on a Sephadex LH-20 column $($ fin $\phi=3.5 \mathrm{~cm} ; \mathrm{HGEL}=22.0 \mathrm{~cm}$ ) eluted with a mixture of $\mathrm{Hex}-\mathrm{CH}_{2} \mathrm{Cl}_{2}-\mathrm{MeOH}(3: 1: 1)$ to yield 10 fractions, 2 of them were purified as follow:

Subfractions 5.1 and 5.3 were subjected to purification by HPLC. For this technique an Agilent1200 chromatograph Quaternary LC Series system was used, equipped with 2 detection systems: UV diode array detector (DAD, G1315D) and a refractive index detector (RIDG1362A). JAIGELSilAMS-043-10 (25 cm x $20 \mathrm{~mm}, 10 \mu \mathrm{m})$ and Ascentis (25 cm x $10 \mathrm{~mm}$ columns, $5 \mu \mathrm{m}$ ) were used.

\section{Fraction $6(\mathrm{MeOH} 100 \%)$}

Fraction 6 (46.5 mg) was purified by Sephadex LH-20 gel filtration chromatography (fin $\phi=3.5 \mathrm{~cm} ; \mathrm{HGEL}=22.0 \mathrm{~cm}$ ) eluted with a mixture of $\mathrm{Hex}-\mathrm{CH}_{2} \mathrm{Cl}_{2}-\mathrm{MeOH}(3: 1: 1)$.

\section{INFRARED SPECTROSCOPY (IR)}

Infrared spectra were performed as film on a Perkin-Elmer FTIR spectrophotometer, model 1600.

\section{Mass SPECTROMETRY (MS)}

For low resolution mass spectra (MS) and high resolution mass spectra (HRMS) a Vg-Micromass model Zab 2F spectrometer (Scientific Instrument Services: SIS), with ionization source electron impact (ionization energy EI, $70 \mathrm{eV}$ and temperature source $220^{\circ} \mathrm{C}$ ) and a Micromass model LCT Premier XE spectrometer, with electrospray (ESI) ionization source of positive and negative mode were used. 


\section{NuCLEAR MAGNETIC RESONANCE (NMR)}

NMR spectra were performed on Bruker Avance 400 (400 $\mathrm{MHz}$ for ${ }^{1} \mathrm{H}$ and $100 \mathrm{MHz}$ for ${ }^{13} \mathrm{C}$ ), Bruker AMX 500 (500 $\mathrm{MHz}$ for ${ }^{1} \mathrm{HNMR}$ and $125.7 \mathrm{MHz}$ for ${ }^{13} \mathrm{CNMR}$ ) and Bruker Avance III 600, equipped with a $5 \mathrm{~mm}$ cryoprobe TCI reverse detection (600 MHz for ${ }^{1} \mathrm{HNMR}$ and $150.0 \mathrm{MHz}$ for $\left.{ }^{13} \mathrm{CNMR}\right)$. All the $2 \mathrm{D}$ experiments ${ }^{1} \mathrm{H}-{ }^{1} \mathrm{H}-\mathrm{COSY}$ and ${ }^{13} \mathrm{C}-{ }^{1} \mathrm{H}-\mathrm{HMBC}$ were run with the same equipment.

For data acquisition, deuterochloroform $\left(\mathrm{CDCl}_{3}\right)$ was used as solvent and chloroform as internal reference standard unless otherwise indicated (7.25 ppm $\delta \mathrm{H} ; 77.0 \mathrm{ppm} \delta \mathrm{C}$ ). Chemical shift values $(\delta)$ are expressed in parts per million (ppm) in relation to the solvent used as internal reference, and coupling constants $(J)$ in Hertz $(\mathrm{Hz})$. The spectroscopic information was processed using SpecManager program (version 6.0), ACD /Labs: Copyright 1997-2002.

\section{Assessment of ANTIBIOTIC ACTIVITY}

The following panel of strains from the Spanish Collection [CECT(Valencia, Spain)] or American Type Culture [ATCC(USA)] were used for this bioassay: Bacillus cereus (ATCC 21772, Gram+), Escherichia coli (ATCC 9637, Gram-), Enterococcus faecalis (ATCC 29212, Gram+), Klebsiella pneumoniae (ATCC 23357, Gram-), Proteus mirabilis (CECT170, Gram-), Staphylococcus aureus (ATCC 6538, Gram+), Salmonella sp. (CECT 456, Gram-) and the yeast Candida albicans (ATCC MYA-2876). These strains were chosen for their chemical and physical characteristics commonly found in aerobic microorganisms.

\section{Minimum INHIBITORY CONCENTRATION (MIC)}

The minimum inhibitory concentration was determined by the broth dilution method (Torres-Beltrán et al. 2012). Two ml of tryptic soy broth medium (TSB, Fluka) and an aliquot of crude or test compound dissolved in dimethylsulfoxide(DMSO) were added to a test tube to achieve a final concentration of 50-100 $\mu \mathrm{g} \mathrm{ml}^{-1}$. The tubes were inoculated with $0.1 \mathrm{ml}$ of an indicator organism suspension. The suspension cell density was maintained in the 1 to $5 \times 10^{5}$ viable units $\mathrm{ml}^{-1}$ range. After a $20-24 \mathrm{~h}$ period at $28^{\circ} \mathrm{C}$ in a shaker, the turbidity degree was determined visually and the viable cells was counted on TSA plates for those tubes that had transparency. A control growth tube was included in the assay, it lacked product but had the same proportion of DMSO. For $C$. albicans yeast YPD medium $[2 \%(\mathrm{w} / \mathrm{v})$ Bactopeptone, $1 \%(\mathrm{w} / \mathrm{v})$ yeast extract and $2 \%(\mathrm{w} / \mathrm{v})$ glucose, $+/-1.5 \%$ agar] was used.

\section{Сутотохіс ACtivity}

The cytotoxicity activity test was performed with 3 cancer cell lines: breast cancer MCF-7 (ATCC HTB-22 TM), cervical cancer HeLa (ATCC CCL-2 TM), and colorectal cancer HCT116 (ATCC CCL-247 TM), obtaining the average inhibitory concentration $\left(\mathrm{IC}_{50}\right)$ values in $\mu \mathrm{g} \mathrm{ml}^{-1}$ after a $24 \mathrm{~h}$ exposition period; then, the absorbance was read at $495 \mathrm{~nm}$. DMSO was used as negative control and etoposide as positive control, both in the same concentrations as the rest of the compounds used in the experiment. In this assay, crude extracts and pure compounds isolated from the active strains were evaluated.

\section{Cell hine culture}

Cells lines used for this assay were stored at $-70^{\circ} \mathrm{C}$ in Bovine Fetal Serum (FBS) 10\% DMSO. The cells were thawed at a temperature of $4^{\circ} \mathrm{C}$ and centrifuged at $4000 \mathrm{rpm}$ for $2 \mathrm{~min}$, then the pellet was resuspended in $1 \mathrm{ml}$ Roswell Park Memorial Institute medium (RPMI) supplemented with $10 \%$ FBS, antibiotic-antimycotic $1 \%$ in glucose $0.5 \%$. The cellular pellet was resuspended in a Petri dish and slowly homogenized. Immediately after homogenization, $10 \mathrm{ml}$ supplemented medium were added and incubated at $37^{\circ} \mathrm{C}$ in a $5 \% \mathrm{CO}_{2}$ atmosphere until a confluent monolayer growth was observed.

\section{Cytotoxic assay}

From the confluent monolayer, the cells were detached from the bottle by trypsinization. Initially they were washed twice with the monolayer of cells, one with $1 \%$ fetal bovine serum (FCS) and the other with $1 \%$ ethylenediaminetetraacetic acid (EDTA), then subsequently $1 \mathrm{ml}$ of $1 \%$ trypsin was added. The mixture was allowed to act for about 1 minute in order to detach the cells that were attached to the support. Cells were deposited in 96-well plates at a density of $5 \times 10^{3}$ cells, and a total volume of $200 \mu \mathrm{l}$ in each well. Plates were incubated for $24 \mathrm{~h}$ at $37^{\circ} \mathrm{C}$ and a $5 \% \mathrm{CO}_{2}$ atmosphere. Once the incubation time had elapsed, $20 \mu \mathrm{l}$ of each test sample $\left(10 \mathrm{mg} \mathrm{ml}^{-1}\right)$ was placed in $200 \mu \mathrm{l}$ of supplemented media in a separate plate. Finally, the cell medium was removed and replaced with $200 \mu \mathrm{l}$ of each sample (sample mixture with supplemented medium), and incubated for $24 \mathrm{~h}$. Each extract or compound as well as the controls and targets were run in triplicate. The positive control contained 10\% DMSO while the negative control RPMI in sterile water. After a $24 \mathrm{~h}$ incubation period, the samples were observed with an inverted 10 or 20x magnification microscope. Subsequently, $20 \mu \mathrm{l}$ of Cell Titer solution was added and incubated for 1 to $2.5 \mathrm{~h}$ at $37^{\circ} \mathrm{C}$, the optical density of the wells was determined with an ELISA reader at 495 nm. 


\section{RESULTS}

The AMS370 strain was collected in Los Angeles Bay, B.C. México (Becerril-Espinosa et al. 2013); the strain was identified as Salinispora arenicola by $16 \mathrm{~S}$ rRNA amplified gene comparison with GenBank database sequences of the $100 \%$ identities to Salinispora arenicola 'A' [strain AMS300, Accession number (gb/ HQ873946)] sequence.

From the AMS370 strain culture, two crude extracts were obtained, the first one, semi-polar fraction, consisted of the EtOAc extraction of the liquid phase of the culture and the second one, the polar fraction, representing the extraction of the residue with methanol.

The semipolar crude extract showed some antibiotic activity (Table 1) being inactive against Candida albicans as well as to all the cancer cell lines assayed. Positive activity was found against Gram- bacteria Klebsiella pneumoniae and the Gram+ bacteria Staphylococcus aureus with a MIC $\leq 100 \mu \mathrm{g} \mathrm{ml}^{-1}$ for both microorganisms

The EtOAc extract was separated by chromatographic methods yielding 8 fractions (Fig. 1) that were monitored by ${ }^{1} \mathrm{HNMR}$ spectra and bioactivity. From the results obtained by the monitoring process, only fractions 2, 4, 5 and 6 were selected for further analysis.
Table 1. Assessment of antibiotic activity semipolar extract of the strain AM S370 / Evaluación de la actividad antibiótica del extracto semipolar de la cepa AMS370

\begin{tabular}{lc}
\hline \multirow{2}{*}{ Strain name } & $\begin{array}{c}\text { Minimum Inhibitory } \\
\text { Concentration (MIC) } \\
\mu \mathrm{g} \mathrm{ml}^{-1}\end{array}$ \\
\cline { 2 - 2 } & $\begin{array}{c}\text { Semipolar fraction } \\
\text { (ETOAc) }\end{array}$ \\
\hline Bacillus cereus & $*$ \\
Escherichia coli & $*$ \\
Enterococcus faecalis & $*$ \\
Klebsiella pneumoniae & $\leq 100$ \\
Proteus mirabilis & $*$ \\
Staphylococcus aureus & $\leq 100$ \\
Salmonella sp. & $*$ \\
Candida albicans & $*$ \\
\hline
\end{tabular}

$*=$ countless or MIC $\geq 100 \mu \mathrm{g} \mathrm{ml}^{-1}$

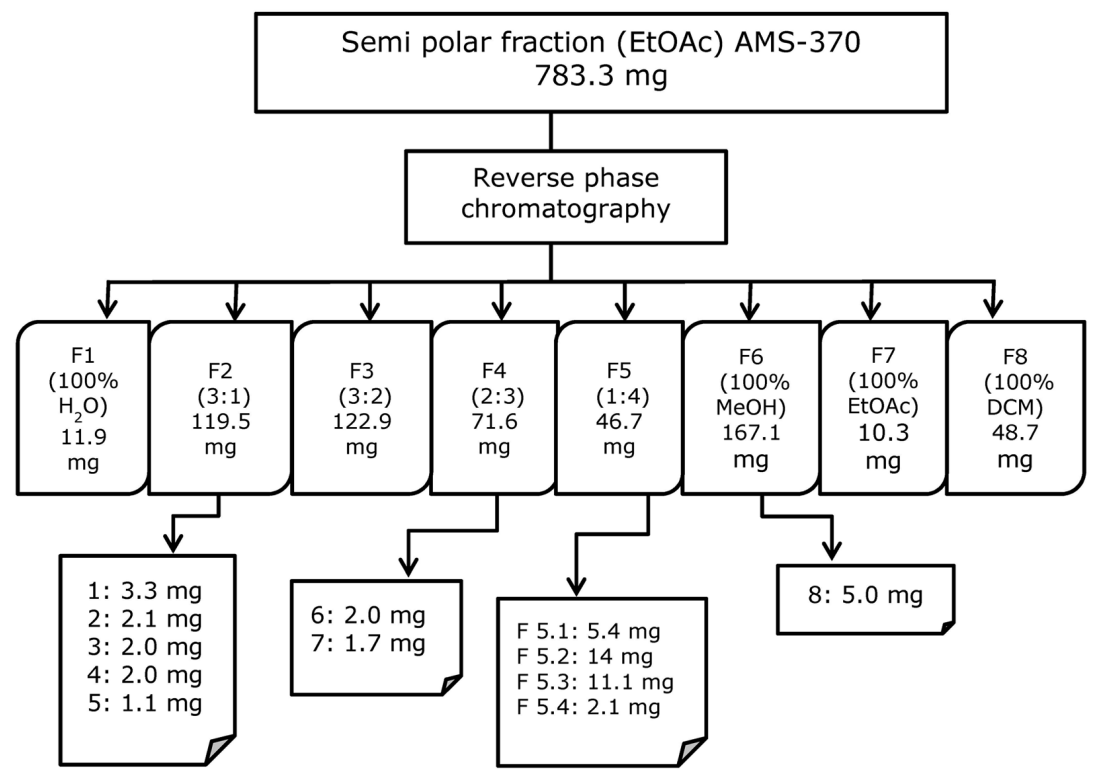

Figure 1. Chromatographic separation of the semipolar fraction (EtOAC) of the strain AM S370 from the Gulf of California, Mexico / Separación cromatográfica de la fracción semipolar (AcOEt) de la cepa AMS370 del Golfo de California, México 
Purification of fraction $2\left(\mathrm{H}_{2} \mathrm{O}-\mathrm{MeOH}(3: 1), 119.5 \mathrm{mg}\right)$ yielded 60 subfractions. This process resulted in the isolation of 5 known compounds, 1 (3.3 mg), 2 ( $2.1 \mathrm{mg}), 3(2.0 \mathrm{mg}), 4$ $(2.0 \mathrm{mg}$ ) and 5 (1.1 mg) (Table 2). By NMR data comparison, compound 1 was identified as 4-Hydroxy-phenyl acetic acid (Zhuravleva et al. 2011). Compound 2 resulted identical to 5Methyl-2-methylene-2,3-dihydro-1 $H$-pyrimidin-4-one, (thymine) previously reported by Ying et al. (2011). Compound $3(2.0 \mathrm{mg}$ ) was identified as $1 H$-Pyrimidine-2, 4-dione (uracile) (Liu et al. 2009). Compound 4 (2.0 mg) was shown to be identical to the synthetic compound 3-Amino-5-hydroxybenzoic acid (Wang et al. 2011) and obtained for the first time as a natural product in this study from the Salinispora genus. Compound 5 was identified as 2-(4-Amino-imidazol-[4,5d]pyridazin-1-yl)-5-hydroxymethyl-4-methyl-tetrahydro-furan3-ol (adenosine) (Patching et al. 2005) (Table 2).
Compound 4 was obtained as an amorphous yellow solid with a molecular ion at $\mathrm{m} / z 153.05[\mathrm{M}]^{+}$, which satisfies the empirical formula $\mathrm{C}_{7} \mathrm{H}_{7} \mathrm{NO}_{3}$ (HRMS 153.0427, calculated 153.0426 for $\mathrm{C}_{7} \mathrm{H}_{7} \mathrm{NO}_{3}$ ), with 5 degrees of unsaturation (Table 2). Its infrared spectrum showed absorptions for hydroxyl, carbonyl and amine groups at 3345, 1690 and $1597 \mathrm{~cm}^{-1}$, respectively. Its ${ }^{13} \mathrm{CNMR}$ spectrum confirmed signals for 7 carbon atoms: one carbonyl at $\delta 170.6 \mathrm{ppm}, 3 \mathrm{sp}^{2}$ methines at $\delta 109.4,107.5$ and $107.4 \mathrm{ppm}$ and 3 olefin quaternary carbons at $\delta 159.3,150.2$ and $133.7 \mathrm{ppm}$.

In the ${ }^{1} \mathrm{HNMR}$ spectrum, 3 aromatic protons were distinguished at $\delta 6.87(\mathrm{dd}, J=1.6,2.1 \mathrm{~Hz}), \delta 6.78 \mathrm{dd}, J=1.3$ $3,2.1 \mathrm{~Hz}$ ) and $\delta 6.37(\mathrm{t}, J=2.1 \mathrm{~Hz})$ ppm (Table 3, Fig. 2).
Table 2. Compounds isolated from the strain AM S370 of Gulf of California, Mexico / Compuestos aislados de la cepa AMS370 del Golfo de California, México

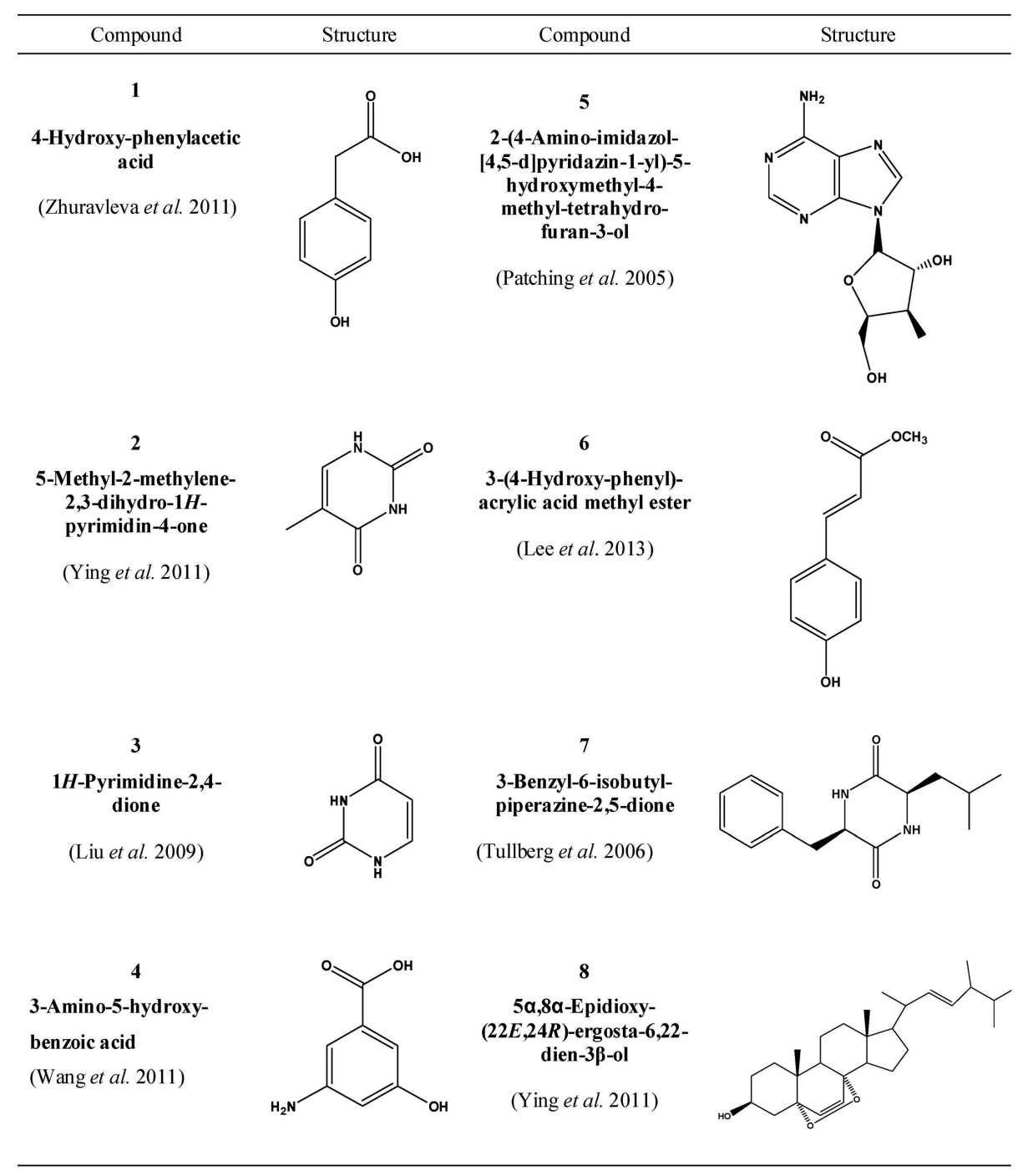


${ }^{13} \mathrm{C}-{ }^{1} \mathrm{HHMBC}$ correlations of the $\mathrm{C}-7$ carbonyl carbon with $\mathrm{H}-2$ and $\mathrm{H}-6$, as well as correlations between $\mathrm{C}-6$ with proton $\mathrm{H}-2$ and $\mathrm{H}-4$ were observed.

Fraction $4\left(\mathrm{H}_{2} \mathrm{O}-\mathrm{MeOH} 2: 3,71.6 \mathrm{mg}\right)$ yielded subfractions 4.1 and 4.2. TLC and ${ }^{1} \mathrm{HNMR}$ analysis of subfraction 4.1 allowed to identify compound $6(2.0 \mathrm{mg})$ as 3-(4-Hydroxyphenyl)-acrylic acid methyl ester (Lee et al. 2013) (Table 2). Subfraction 4.2 yielded compound 7 ( $\mathrm{tr}=42 \mathrm{~min} 100 \%$ EtOAc), identified as3-Benzyl-6-isobutyl-piperazine-2,5-dione (Tullberg et al. 2006) (Table 2).

In the case of fraction $5\left(\mathrm{H}_{2} \mathrm{O}-\mathrm{MeOH} 1: 4,46.5 \mathrm{mg}\right)$, several sub-fractions were obtained according to TLC and ${ }^{1} \mathrm{HNMR}$ spectroscopy. They were classified as follows: $5.1(5.4 \mathrm{mg})$, $5.2(14 \mathrm{mg}), 5.3(11.1 \mathrm{mg}), 5.4(2.1 \mathrm{mg})$ and $5.5(12.2 \mathrm{mg})$.

Table 3. Nuclear Magnetic Resonance data of compound 4 (3-amino5-hydroxy benzoic acid) (CD $0 \mathrm{OD}, 400 \mathrm{M} \mathrm{Hz}, \delta \mathrm{ppm},()) \mathrm{Hz}) /$ Datos de Resonancia Magnética Nuclear del compuesto 4 (ácido-3-amino-5hidroxibenzóico) $\left(\mathrm{CD}_{3} \mathrm{OD}, 400 \mathrm{MHz}, \delta \mathrm{ppm},(\mathrm{J}) \mathrm{Hz}\right)$

\begin{tabular}{ccccc}
\hline$\#$ & $\delta_{\mathrm{H}}$ & $\delta_{\mathrm{C}}$ & $\begin{array}{c}{ }^{1} \mathrm{H}-{ }^{1} \mathrm{H} \\
\mathrm{COSY}\end{array}$ & $\begin{array}{c}{ }^{13} \mathrm{C}-{ }^{1} \mathrm{H} \\
\mathrm{HMBC}\end{array}$ \\
\hline 1 & --- & 133.7 & & \\
2 & $\begin{array}{c}6.87(1 \mathrm{H}, \mathrm{dd}, \\
J=1.5,2.1)\end{array}$ & 109.4 & $\mathrm{H}-4$ & $\mathrm{H}-6, \mathrm{H}-4$ \\
& & & & \\
3 & -- & 150.2 & & $\mathrm{H}-4$ \\
4 & $6.37(1 \mathrm{H}, \mathrm{t}$, & 107.5 & $\mathrm{H}-6$ & $\mathrm{H}-6$ \\
5 & $J=2.1,4.2)$ & 159.3 & & $\mathrm{H}-4, \mathrm{H}-6$ \\
6 & --- & 107.4 & & $\mathrm{H}-2, \mathrm{H}-4$ \\
7 & $\quad \begin{array}{c}5=1.3,2.1) \\
7\end{array}$ & 170.6 & & $\mathrm{H}-2, \mathrm{H}-6$ \\
\hline
\end{tabular}

Subfractions 5.1 and 5.3 were subjected to HPLC. No purification process enabled us to obtain a pure compound, however, both sub-fractions obtained by HPLC were active with a MIC $\geq 50 \mathrm{mg} \mathrm{ml}^{-1}$, but the sample amounts (mg) were insufficient to continue with the isolation process.

The purification of fraction $6(100 \% \mathrm{MeOH}, 46.5 \mathrm{mg})$ resulted in the isolation of compound $8(5 \mathrm{mg})$, after comparison of its NMR data with those reported for the original compound it was identified as 5,8-epidioxy-(22E,24R)-ergosta-6,22-dien3-ol (ergosterol peroxide) (Ying et al. 2011) (Table 2).

\section{Antibiotic ACTIVITy}

The crude extract showed only antibacterial activity, as well as the semi-polar extract. All the fractions selected from the semipolar extract $(2,4,6$, and their subfractions) were inactive, only fraction 5 showed active against bacterial strains $S$. aureus and $K$. pneumoniae, with a MIC $\leq 100 \mu \mathrm{g} \mathrm{ml}^{-1}$ (Table 4), similar to that obtained from the crude extract. Furthermore, after purification, sub-fractions 5.1 to 5.3, showed the same or an increment of such activity (MIC $\geq 50 \mu \mathrm{gml}^{-1}$ for 5.1 and 5.2 and $\geq 100 \mu \mathrm{gml}^{-1}$ for 5.3 subfractions). No activity was found against the rest of the tested bacteria.

All the 8 isolated compounds were tested against the same cells lines that the original extract tested, resulting inactive with $\mathrm{MIC} \geq 100 \mu \mathrm{gml}^{-1}$.

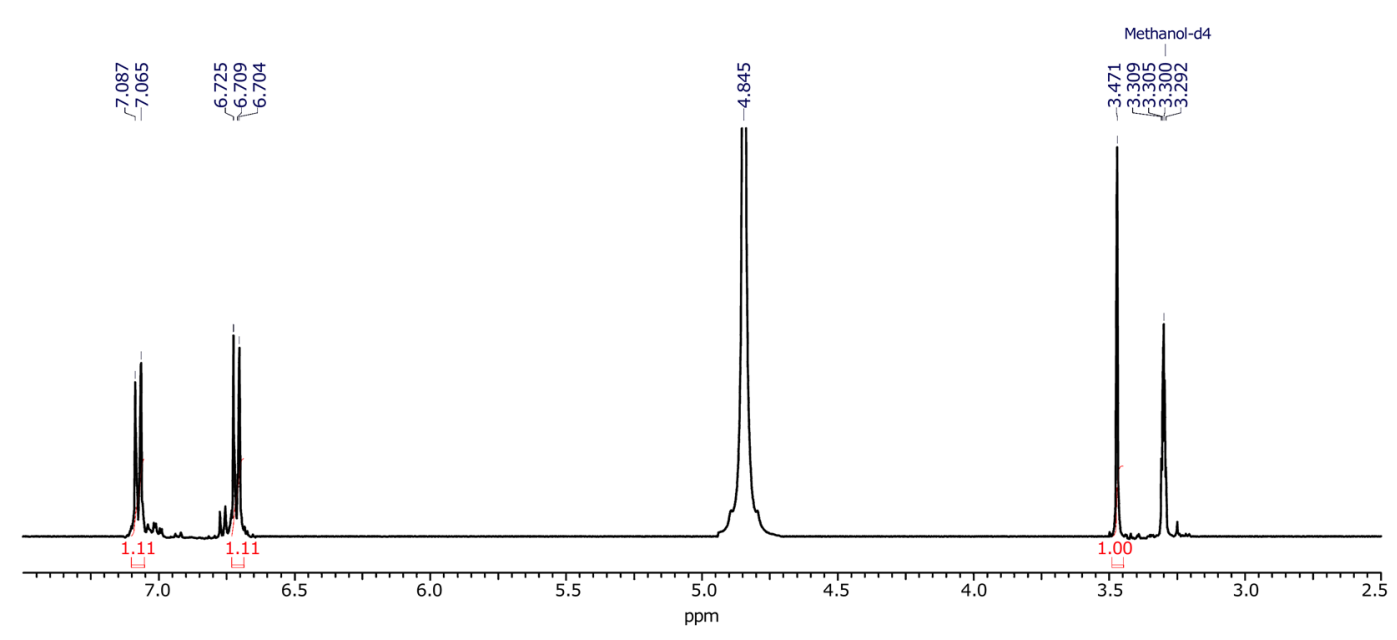

Figure 2. ${ }^{1} \mathrm{HNM}$ R spectra of the compound 4, (3-amino-5-hydroxy benzoic acid) $\left[\mathrm{CD}_{3} \mathrm{OD}, 400 \mathrm{M} \mathrm{Hz}, \delta \mathrm{ppm},(\mathrm{J}) \mathrm{Hz}\right] /$ Espectro de Resonancia Magnética Nuclear protónica del compuesto 4 (ácido-3-amino-5-hidroxibenzóico) $\left[\mathrm{CD}_{3} \mathrm{OD}, 400 \mathrm{MHz}, \delta\right.$ ppm, (U) Hz] 
Table 4. Evaluation of the minimum inhibitory concentration of F5 sub-fractions against the $\mathbf{S}$. aureus y $\mathrm{K}$. pneumoniae strains / Evaluación de la concentración inhibitoria mínima de las subfracciones $\mathrm{F} 5$, frente a las cepas indicadoras $\mathrm{S}$. aureus y $\mathrm{K}$. pneumoniae

\begin{tabular}{ccc}
\hline F5 Sub-fractions & S. aureus & K. pneumoniae \\
\hline 5.1 & $\geq 50 \mu \mathrm{gml}^{-1}$ & $\geq 50 \mu \mathrm{gml}^{-1}$ \\
5.2 & $\geq 50 \mu \mathrm{gml}^{-1}$ & $\geq 50 \mu \mathrm{gml}^{-1}$ \\
5.3 & $\geq 100 \mu \mathrm{gml}^{-1}$ & $\geq 100 \mu \mathrm{gml}^{-1}$ \\
5.4 & $*$ & $*$ \\
5.5 & $*$ & $*$ \\
\hline
\end{tabular}

$*=$ count less

\section{DiscuSSION}

The distribution of genus Salinispora in the Gulf of California has been reported to extend from Los Angeles Bay, Baja California to Loreto Bay, Baja California Sur. It is important to state that the AMS370 strain as well as $88 \%$ of the strains sequenced by Becerril-Espinosa et al. (2013) belongs to the S. arenicola species.

The fractions 2, 4, 5 and 6 obtained from the semi-polar phase of the original extract were purified. From fraction 2 compounds 1, 2, 3, 4 and 5 were obtained and identified as 4Hydroxy-phenyl acetic acid (Zhuravleva et al. 2011), 5-Methyl2-methylene-2,3-dihydro-1H-pyrimidin-4-one (Ying et al. 2011), 1 H-Pyrimidine-2, 4-dione (Liu et al. 2009), 3-Amino5-hydroxy-benzoic acid (Wang et al. 2011) and 2-(4-Aminoimidazol-[4,5-d]pyridazin-1-yl)-5-hydroxymethyl-4-methyltetrahydro-furan-3-ol (Patching et al. 2005), respectively. Even though compound 4 (3-Amino-5-hydroxy-benzoic acid) has been obtained previously as an intermediate product in the Ferrimycin A synthesis (Bickel et al. 1966), this is the first time it is found as a natural product in the Salinispora genus.

Despite the inactivity revealed for compound 1 in this work, Aissa et al. (2012) found antimicrobial activity against the Gram+ bacteria Bacillus cereus, Enterococcus faecalis, Staphylococcus aureus, Bacillus subtilis, Staphylococcus xylosus and Gram- Klebsiella pneumoniae, Escherichia coli, Enterobacter cloacae and Pseudomona aeruginosa as well as an antioxidant capacity equivalent to $0.87 \pm 0.0015$ TEAC $\mathrm{mM}$ Trolox $\mathrm{l}^{-1}$ (ABTS assay) for the same compound.

Yan et al. (2012) reported a low cytotoxic activity of the compounds 2 and 3 against SF-268, NCl-H460, K-562,
SMMC-7721 y SGC-7901 cancer cell lines $\left(\mathrm{IC}_{50}>100 \mu \mathrm{g}\right.$ $\left.\mathrm{ml}^{-1}\right)$.

Compound 5 was reported to possess activity as antithrombotic, neurotransmission inhibitor and vasodilator; also, several analogs of this compound showed anticancer, antifungal and antiviral activity. It has been reported that the 5'-hydroxyl group in the molecule can enter nucleoside metabolic pathways (Moukha-chafiq \& Reynolds 2013).

Compound 6 has been reported with weak antibiotic activity with inhibition diameters between $8.0-11.5 \mathrm{~mm}$ at $10 \mathrm{mg} \mathrm{ml}^{-1}$ (disc diffusion method) against E. coli, P. aeroginosa, B. subtilis and S. aureus (Venkateswarlu et al. 2006).

The structure elucidation of compound 4 was based on the main characteristics of the ${ }^{13} \mathrm{CNMR}$ data obtained. The existence of one carbonyl group and $6 \mathrm{sp}^{2}$ carbons, and the need to meet the 5 degrees of unsaturation indicated by its empirical formula $\left(\mathrm{C}_{7} \mathrm{H}_{7} \mathrm{NO}_{3}\right)$, suggests that 4 must possess a single ring that should be a tri substituted aromatic ring.

${ }^{1} \mathrm{HNMR}$ and two dimensional experiments ${ }^{1} \mathrm{H}-{ }^{1} \mathrm{H} \mathrm{COSY}$ and ${ }^{1} \mathrm{H}_{-}{ }^{13} \mathrm{C}$ HMBC confirmed compound 4 structures (Table 2). Long-range COSY correlations between $\mathrm{H}-2(J=1.5 \mathrm{~Hz})$ and $\mathrm{H}-6$, and between $\mathrm{H}-4$ and $\mathrm{H}-6(\mathrm{~J}=2.1 \mathrm{~Hz})$ indicated that protons $\mathrm{H}-2, \mathrm{H}-4$ and $\mathrm{H}-6$ are all meta positioned.

${ }^{1} \mathrm{H}-{ }^{13} \mathrm{C}$ HMBC correlations of carbonyl C-7 with $\mathrm{H}-2$ and H-6 established the position of the carboxylic group on $\mathrm{C}-1$. $\mathrm{C}-3$ showed $\delta 150.2 \mathrm{ppm}$ and $\mathrm{C}-5$ at $\delta 159.3 \mathrm{ppm}$ indicating that the amine must be at C-3 and the hydroxyl group at C-5. These data allowed confirmation of the chemical structure of compound 4 as 3-amino-5-hydroxy-benzoic acid. In this paper was described, for the first time, the isolation of this acid as a natural product in the Salinispora genus, which was previously obtained by synthetic pathways (Wang et al. 2011) and was claimed for the first time as a natural product, inferring the result by the reduction in the ${ }^{13} \mathrm{C}$ content of the carboxyl group from 85 to 52 atom $\%$ excess over natural abundance during the fermentation experiment with unlabeled material produced by S. verticillatus (Kibby \& Rickards 1981). However, never until this investigation, was isolated as a natural product per se.

Ergosterol peroxide (8) is other interesting compound obtained in this work. It has been reported and isolated from a number of organisms, including bacteria. According to published results (Ying et al. 2011), 8 presents mild cytotoxic activity against the SNU-1 cell line (human gastric tumor), SNU-C4, SNU-354 and Sarcoma-180 (Kyong et al. 2001). In addition, activities such as anti-inflammatory (Lishuai et al. 2013), immunosuppressive (Fujimoto et al. 1994) and antiatherosclerosis (Kim et al. 2005) have been reported. 
However we did not find any cytotoxic, anti-fungicidal or antibacterial activity for this compound.

In conclusion we can say that AMS370 strain was identified as Salinispora arenicola 'A' on the basis of its 16S rRNA sequence analysis. Chromatographic purification and structural determination of 8 known compounds, one of them, 3-amino5-hydroxybenzoic acid, reported for the first time as a natural product in Salinispora genus, were made. Fraction 5 was responsible for the bioactivity of the crude extract, with antibacterial activity against Staphylococcus aureus and Klebsiella pneumoniae strains $\left(\mathrm{MIC}_{50} \leq 100 \mu \mathrm{g} \mathrm{ml}^{-1}\right.$ ). Actinobacteria from marine sediments such as the ones found in the Gulf of California with the capability to biosynthesize bioactive compounds may have a great impact in human health since they are a potential source of compounds with very promising antibacterial activity.

\section{ACKNOWLEDGMENTS}

We thank the financial support provided by the UABC through the XV Internal Assembly, and the Consejo Nacional de Ciencia y Tecnología (México) 2011 Basic Science Grant No. 168484 and by the Ministerio de Ciencia e Innovación (SAF200908039; SAF2010-16858). We also thank the CONACYT for the pre-doctorate fellowship given to FCM (No. 206455) and to AMIM (No. 252250).

\section{LITERATURE CITED}

Ahmed L, PR Jensen, KC Freel, R Brown, LJ Amanda, BY Kim \& M Goodfellow. 2013. Salinispora pacifica sp. nov., an actinomycete from marine sediments. Antonie van Leeuwenhoek 103(5): 1069-1078.

Aissa I, M Bouaziz, F Frikha, RB Mansour \& Y Gargouri. 2012. Synthesized tyrosyl hydroxyphenylacetate, a novel antioxidant, anti-stress and antibacterial compound. Process Biochemistry 47(12): 2356-2364.

Becerril-Espinosa A, KC Freel, PR Jensen \& IE SoriaMercado. 2013. Marine actinobacteria from the Gulf of California: Diversity, abundance and secondary metabolite biosynthetic potential. Antonie van Leeuwenhoek 103(4): 809819.

Bérdy J. 2005. Bioactive microbial metabolites. Journal of Antibiotics 58(1): 1-26.

Bickel L, P Mertens, V Prelog, J Seibl \& A Walser. 1966. Stoffwechselprodukte von mikroorganismen-53 Ueber die konstitution von ferrimycin $A_{1}$. Tetrahedron 22 (Suppl 8): 171179.

Blunt JW, VL Calder, GD Fenwick, RJ Lake, JD McCombs, MHG Munro \& NB Perry. 1987. Reverse phase flash chromatography: A method for the rapid partitioning of natural products extracts. Journal of Natural Products 50(2): 290-292.
Bose U, AK Hewavitharana, ME Vidgen, YK Ng, PN Shaw, JA Fuerst \& MP Hodson. 2014. Discovering the recondite secondary metabolome spectrum of Salinispora species: A study of inter-species diversity. PLoS One 9(3): e91488.

Bose U, AK Hewavitharana, YK Ng, PN Shaw, JA Fuerst \& MP Hodson. 2015. LC-MS-Based Metabolomics Study of Marine Bacterial Secondary Metabolite and Antibiotic Production in Salinispora arenicola. Marine Drugs 13(1): 249-266.

Bull AT \& JEM Stach. 2007. Marine actinobacteria: new opportunities for natural product search and discovery. Trends in Microbiology 15(11): 491-499.

De la Lanza EG. 2004. Gran escenario de la zona costera y oceánica de México. Ciencias 76: 4-13.

Ellaiah P, T Ramana, K Raju, P Sujatha \& A Sankar. 2004. Investigation on marine actinomycetes from Bay of Bengal near Kakinada coast of Andhra Pradesh. Asian Journal of Microbiology, Biotechnology and Environmental Science 6(1): 53-56.

Feling RH, GO Buchanan, TJ Mincer, CA Kauffman, PR Jensen \& W Fenical. 2003. Salinosporamide A: A highly cytotoxic proteasome inhibitor from a novel microbial source, a marine bacterium of the new genus Salinospora. Angewandte Chemie International Edition 42(3): 355-357.

Fenical W \& PR Jensen. 2006. Chemical studies of marine bacteria: Developing a new resource. Nature Chemical Biology 2(12): 666-673.

Fenical W, PR Jensen, MA Palladino, KS Lam, K Lloyd \& BC Potts. 2009. Discovery and development of the anticancer agent salinosporamide A (NPI-0052). Bioorganic \& Medicinal Chemistry 17(6): 2175-2180.

Fujimoto H, M Nakayama, Y Nakayama \& M Yamazaki. 1994. Isolation and characterization of immunosuppressive components of three mushrooms, Pisolithus tinctorius, Microporus flabelliformis and Lenzites betulina. Chemical and Pharmaceutical Bulletin 42(3): 694-697.

Han X, C Cui, Q Gu, W Zhu, H Liu \& J Gu. 2005. ZHD0501, a novel naturally occurring staurosporine analog from Actinomadura sp. 007.Tetrahedron Letters 46(36): 61376140.

Jemimah NS, VM Srinivasan \& CS Devi. 2011. Novel anticancer compounds from marine actinomycetes: A review. Journal of Pharmacy Research 4(4): 1285-1287.

Jensen PR \& FM Lauro. 2008. An assessment of actinobacterial diversity in the marine environment. Antonie van Leeuwenhoek 94(1): 51-62.

Jensen PR \& C Mafnas. 2006. Biogeography of the marine actinomycete Salinispora. Environmental Microbiology 8(11): 1881-1888.

Kibby JJ \& RW Rickards. 1981. The identification of 3-amino5-hydroxybenzoic acid as a new natural aromatic amino acid. The Journal of Antibiotics 34(5): 605-607. 
Kim DH, SJ Jung, IS Chung, YH Lee, DK Kim, SH Kim, BM Kwon, T Jeong, MH Park, NS Seoung \& NI Baek. 2005. Ergosterol peroxide from flowers of Erigeron annuus L. as an anti-atherosclerosis agent. Archives of Pharmacal Research 28(5): 541-545.

Kyong SK, SJ Young, HK Young, WH Jin \& WK Ha. 2001. Cytotoxic activities of acetoxyscirpenediol and ergosterol peroxide from Paecilomyces tenuipes. Life Sciences 69(2): 229-237.

Lee SY, E Moon, SY Kim \& KR Lee. 2013. Quinic acid and derivatives from Pimpinella brachycarpa exert antineuroinflammatory activity in lipopolysaccharide-induced microglia. Bioorganic \& Medicinal Chemistry Letters 23(7): 2140-2144.

Lishuai M, Ch Haixia, D Peng \& L Xueming. 2013. Antiinflammatory and anticancer activities of extracts and compounds from the mushrooms Inonotus obliquus. Food Chemistry 139(1): 503-508.

Liu RH, H Luo, YL Li, M Yang, XK Xu, HL Li, YH Shen, C Zhang, J Su \& WD Zhang. 2009. N-containing compounds from the traditional Chinese medicine ChanSu. Chemical Natural Compounds 45(4): 599-600.

Maldonado LA, W Fenical, PR Jensen, CA Kauffman, TJ Mincer, AC Ward, AT Bull \& M Goodfellow. 2005. Salinispora arenicola gen. nov., sp. nov. and Salinispora tropica sp. nov., obligate marine actinomycetes belonging to the family Micromonosporaceae. International Journal of Systematic and Evolutionary Microbiology 55(5): 1759-1766.

Mincer TJ, PR Jensen, CA Kauffman \& W Fenical. 2002. Widespread and persistent populations of a major new marine Actinomycete taxon in ocean sediments. Applied and Environmental Microbiology 68(10): 5005-5011.

Mincer TJ, W Fenical \& PR Jensen. 2005. Culturedependent and culture-independent diversity within the obligate marine actinomycete genus Salinispora. Applied and Environmental Microbiology 71(11): 7019-7028.

Moukha-chafig O \& RC Reynolds. 2013. Parallel solutionphase synthesis of an adenosin analog library. ACS Combinatorial Science 15(3): 147-152.

Ng YK, MP Hodson, AK Hewavitharana, V Bose, PN Shaw \& JA Fuerst. 2014. Effects of salinity on antibiotic production in sponge derived Salinispora actinobacteria. Journal of Applied Microbiology 117(1): 109-125.

Olano C, C Méndez \& JA Salas. 2009. Antitumor compounds from marine actinomycetes. Marine Drugs 7(2): 210-248.

Patching SG, SA Baldwin, AD Baldwin, JD Young, MP Gallagher, PJF Henderson \& RB Herbert. 2005. The nucleoside transport proteins, NupC and NupG, from Escherichia coli: specific structural motifs necessary for the binding of ligands. Organic \& Biomolecular Chemistry 3(3): 462-470
Tian XP, XY Zhi, Y Qiu, YQ Zhang, SK Tang, LH Xu, S Zhang \& WJ Li. 2009. Sciscionella marina gen. nov., sp. nov., a marine actinomycete isolated from a sediment in the northern South China Sea. International Journal of Systematic and Evolutionary Microbiology 59(2): 222-228.

Torres-Beltrán M, F Cardoso-Martínez, N MillánAguiñaga, A Becerril-Espinosa \& IE Soria-Mercado. 2012. Evaluation of the Gulf of California as a potential source of bioactive marine actinobacteria. Ciencias Marinas 38(4): 599-609.

Tullberg M, M Grøtli \& K Luthman. 2006. Efficient synthesis of 2,5-diketopiperazines using microwave assisted heating. Tetrahedron 62(31): 7484-7491.

Venkateswarlu S, MS Ramachandra, AV Krischnaraju, G Trimurtulu \& GB Subbaraju. 2006. Antioxidant and antimicrobial activity evaluation of polyhydroxycinnamic acid ester derivatives. Indian Journal of Chemistry 45B: 252-257.

Wang Y, J Xiang \& H Jiang. 2011. Halide-Guided Oligo(aryltriazole-amide)s Foldamers: Receptors for multiple Halide Ions. Chemistry a European Journal 17(2): 613-619.

Williams PG, ED Miller, RN Asolkar, PR Jensen \& W Fenical. 2007a. Arenicolidas A-C, 26-membered ring macrolides from the marine actinomycete Salinispora arenicola. The Journal of Organic Chemistry 72(14): 50255034.

Williams PG, RN Asolkar, T Kondratyuk, JM Pezzuto, PR Jensen \& W Fenical. 2007b. Saliniketals A and B, bicyclic polyketides from the marine actinomycete Salinispora arenicola. Journal of Natural Products 70(1): 83-88.

Yi H, P Schumann, K Sohn \& J Chun. 2004. Serinicoccus marinus gen. nov., sp. nov., a novel actinomycete with Lornithine and L-serine in the peptidoglycan. International Journal of Systematic and Evolutionary Microbiology 54(5): $1585-1589$.

Ying YM, ZJ Zhan, ZS Ding \& WG Shan. 2011. Bioactive metabolites from Penicillium sp. P-1, a fungal endophyte in Huperzia serrata. Chemistry of Natural Compounds 47(4): 541-546.

Zhuravleva OI, EV Leshchenko, Sh Afiyatullov, MP Sobolevskaya, VA Denisenko \& LS Shevchenko. 2011. Metabolites from the marine actinobacterium Streptomyces sp. KMM 7210. Chemistry of Natural Compounds 47(3): 494-495. 